\title{
Is There a Relationship between Creativity and Mathematical Creativity?
}

\author{
Elif Esra Arikan ${ }^{1}$ \\ ${ }^{1}$ Primary Education Department, Istanbul Sabahattin Zaim University, Istanbul, Turkey \\ Correspondence: Elif Esra Arikan, Primary Education Department, Istanbul Sabahattin Zaim University, Istanbul, \\ Turkey. E-mail: elif.arikan@izu.edu.tr
}

Received: May 24, 2017

doi:10.5539/jel.v6n4p239

\author{
Accepted: July 13, 2017 \\ Online Published: July 25, 2017 \\ URL: http://doi.org/10.5539/jel.v6n4p239
}

\begin{abstract}
The aim of this study is to examine the mathematical creativity of individuals who think they have creative thinking skills. Forty-four teachers who work in private schools participated in this study and they have their pedagogical formation training from a public university in order to be a public teacher. Also participants have at least one year of experience. Mixed method research is defined as combining qualitative and quantitative methods, approaches and concepts in successive studies (Creswell, 2003). This study was determined as a mixed method research since data first analyzed by content analysis (qualitative) and then relationship and comparison analysis (quantitative). In order to analyse problem situation of the study, two testing instruments one of which is ready to use were utilized. Problem solving and problem posing test as two items was developed by the researcher. On item was given to participants as a geometry problem in the testing instrument and they were asked to solve this problem by using as many different methods as they can. The other item was given to participants as a semi-structured geometry situation. They were asked to pose as many problems as they can by using this situation. Data obtained from solving draft were divided into categories in terms of flexibility, fluency and originality according to content analysis from qualitative data analyses for each participants.
\end{abstract}

As a result of the study, according to the teachers' creativity that they stated, we can talk about their mathematical creativity only if they can pose an authentic problem.

Keywords: creativity, mathematical creativity, problem solving and problem posing

\section{Introduction}

\subsection{Explore Importance of the Problem}

People use their thinking ability to overcome the difficulties that they face with in their lives (Fisher, 2005). While using this ability, people try to find solutions, which will enable them to overcome the problems that they encountered. If they have creativity, they solve the problem and even seek for alternative solution methods or optimum solution. Besides, they realize the missing parts while trying to choose a suitable strategy in problem solving process (Torrance, 1973).

Creativity is the skill for finding unique solutions by trying and using different strategies in accordance with the abilities and experiences of the person who encounters a problem (Wakefield, 1992). Thanks to this skill, a new and unique thinking or product is presented (Güleryüz, 2001). Creativity includes both creating a new product and presenting new ideas by discovering new correlations between ideas (Aktamış \& Ergin, 2006). In addition to this, activities like renewing or making a new product more useful are also involved in creativity (Sönmez, 1993). In short, creativity means presenting a new, authentic and valuable product or idea for the sake of humanity (Coade, 1997; Leonard \& Swap, 1999; Robinson, 2001).

One of the topics discussed in literature about creativity is the issue whether a recently developed produced idea or product need to be "practical" or not. Sriraman (2009) points out that it is not necessary to have "practical" ideas but it is sufficient to have something authentic and new. While producing new theories from an old theory, it may not be possible to use or transfer this into real life. However, producing a new theory is also a creativity work.

This article is the expanded version of the report presented the Third International Eurasian Educational Research Congress. 
When we analyze creativity in terms of school mathematics, it is not enough to guide students to solve mathematics problems but at the same time, it should create opportunities that allow them to improve their creativity. On the contrary, many people advocate that it is not possible to improve mathematical creativity by asserting the fact that mathematics is a chain of rules. Even the correlation between mathematics and creativity is subject to discussions. Education, which does not aim to discover something new in mathematics lesson, is the reason for this perception (Gregoire, 2016).

Meissner (1999) stated that there could be people who think that teaching mathematics, creativity is not overlapping since mathematics lessons have been carried out by using traditional methods, and they do not give any chances to think creatively.

Guilford (1950) explained creativity with a three-dimensional mind model as flexibility, fluency and authenticity (Sriraman et al., 2011). Balka (1974) is seen as the first researcher who applied this three-dimensional mind model (which is known as the components of creativity stated as flexibility, fluency and authenticity) to mathematics when we analyze the literature. He suggested the idea that mathematical creativity can be tested by analyzing the solution of problems posed about real life (Silver, 1997). Flexible thinking is to search for different methods by dealing with a problem from different perspectives (Lubart, 2003).

There has not been a universal consensus about the definition of the creativity of mathematics as in the concept of creativity. However, researchers who been trying to embody this definition discussed mathematical creativity in their studies as a thinking process together with producing an authentic material (Chamberlin \& Moon, 2005; Ervynck, 1991; Haylock, 1997; Krutetskii, 1976; Laycock, 1970; Leikin, 2009; Sriraman, 2005).

Researchers who accepts mathematical creativity as a thinking process:

Krutetski (1976) described finding solution ways of an uncomplicated mathematical problem, discovering new theories and finding new proof to the current theories from different methods and finding unique ways to solve a subroutine mathematical problem as a sign of mathematical creativity.

Tammadge (1979) argues that a person who is discovering a relation between unrelated ideas about mathematics at first sight have mathematical creativity.

According to Haylock (1987) a person who is mathematically creative is able to beat constant thinking thanks to his/her divergent and flexible thinking. The study of Ima (2000a) supports this definition. Ima asked questions, which were divided into two categories to middle, school students. The questions in the first category can be solved by using known methods and certain methods. What is expected from the students in this category is to find a solution by using a different method without using the known method. The authenticity of the students' responses was tried to be identified. As result of the study what was discovered is the fact that students who produced authentic ideas for the second category problems solved the problems in the first category by using a different method.

Yee (2005) stated that it is necessary to use both problems which only have a single correct answer and to use open-ended questions that can be answered by using multiple methods to make students think creatively. For the reason of this thinking, it was suggested to have the process of analysing all the assumptions before making a choice among various solutions.

Leikin and Lev (2013) who used to solve maths problems by using multiple methods in determining mathematical creativity gave problems to the students who were divided into three categories; gifted students, students who are good at maths, students who have an average achievement and asked them to solve problems by using various methods. When the responses were evaluated in terms of flexibility, fluency and authenticity, it is understood that in these three categories, there are meaningful differences between gifted students - students who are good at maths and students who are good at maths - students who have an average achievement. By moving from these findings, it is concluded that solving a maths problem by using different methods can be used in determining mathematical creativity.

There are studies in the literature claiming there is a correlation in the positive direction between creativity and mathematical creativity (Haylock, 1985; Lee et al., 2003).

There are studies in the literature claiming there is a positive correlation between creativity and mathematical creativity (Haylock, 1985; Lee et al., 2003). There has not been a universal consensus about the definition of the creativity of mathematics as in the concept of creativity. However, researchers who been trying to embody this definition discussed mathematical creativity in their studies as a thinking process together with producing an 
authentic material (Chamberlin \& Moon, 2005; Ervynck, 1991; Haylock, 1997; Krutetskii, 1976; Laycock, 1970; Leikin, 2009; Sriraman, 2005).

\subsection{Literature Review}

When we consider problem as a difficulty that someone faces with, people need to use features like authentic methods, creative ideas and high level thinking skills to solve a problem (Tertemiz \& Çakmak, 2007). Since problem solving is an activity that we need in all parts of our lives, it is a skill that we need to be able to survive (Skemp, 1986). One of the results which was highlighted in the studies is that problem solving is an inevitable part of doing mathematics (Karataş \& Güven, 2004; NCTM, 1980; Çakmak, 2005). Conceptual and operational knowledge should be blended in improving problem solving skills (Bernardo, 1999). The factors affecting problem solving skills are as in the following; attitude developed towards a problem, understanding and reasoning and experience (Van de Walle, 1978). Students should not only solve problems regarding school mathematics but also they need to solve problems including real life problems so that they can both stay away from route learning and have opportunities in which they gain new experiences bout problem solving (Salman, 2012). Some of the features that an individual need to possess in a civilized society is to have flexible, critical and creative thinking and also to have communication, comparison and reasoning skills (Özden, 1998). In traditional education, problem-solving process is perceived to have a linear order and the learner follows the way which is taught by the teacher. For this reason, students' critical and creative thinking skills become blunt (Evancho, 2000). In order to become individuals who can discover connections and who can make inferences, we should stay away from parrot like teaching in terms of showing the fact that mathematics is not a bunch of numbers (Schoenfeld, 1992). Leikin (2009) emphasized the necessity that we should search for multiple solution methods for a single problem. He also pointed out that finding a different and authentic method among these solution methods is a sign of mathematical creativity.

Students should have opportunities to pose problems about the topic that they are studying and so that their curiosity about the topic will be revealed (Hiebert et al., 1996). It is stated that problem-posing activities are important in terms of avoiding a teacher-centred curriculum (Shor, 1992). Freire (1970) expresses that problem posing is a communication method that enables social interaction. Thanks to problem posing, teachers can get information about the topics and subjects which students are interested and curious about (Freire, 1970).

Problem posing process affects problem-solving skills positively (Grundmeier, 2003). For this reason, problem posing like problem solving is seen as an activity, which is in the centre of mathematics (Silver, 1997). As problem posing means approaching a topic from different perspectives, it requires deep thinking. Teachers and students are important factors in having efficient problem posing activities. Students need a classroom environment, which does not humiliate students because of their authentic, interrogative productions while posing problems. Teachers are the ones who will provide this environment (Moses, Bjork, \& Goldenberg, 1993). Students try to produce original ideas to find better in each problem posing activity so that their creativity can consolidate. While converting a case into a problem, they start paying attention to logical correlations and formatting it as a question. Their problem solving skills becomes stronger while questioning whether a problem that was posed by them has a solution (Cai, 1998; Canköy \& Darbaz, 2010; English, 1997; Silver, 1997).

It is asserted that whether to have creative thinking skills or not can be tested through responses given by students to the questions which have multiple solutions. Moreover, the fact that students solve an open-ended maths problem with an authentic method and obtain an authentic response thanks to this gives us ideas about their creativity (Lee \& Seo, 2003).

Although it is stated that creativity is necessary sometimes in order to pose a maths problem (Dillon, 1988; Haylock, 1987), there are studies involving the statement which expresses the fact that we cannot talk about a direct correlation between mathematical creativity and problem posing (Silver, 1994)

Wertheimer (1947) cited the point which was emphasized by Einstein as asking the right question is more important than finding the correct answer and it is also necessary to use thinking not only for problem solving but also for designing a "problem in the mind". Jay and Perkins (1997) stated that posing a problem or re-producing a problem through making some changes on the same problem is the key for creativity. A similar conclusion was also stated by Silver (1997). In research-based mathematics teaching, problem solving and problem posing activities contribute to creativity of the students. The first step of a problem -"understanding the problem"- can actually be a clue to display a creative work (Csikszentmihalyi \& Getzels, 1970). Although it was not a study which is supported by empiric evidences, Yuan (2009) stated this fact in his doctoral thesis. For this reason, in addition to determining similarities and differences of Chinese and American students, the existence of correlation between problem posing and creativity was also questioned. Students from Shanghai and Jiaozhou 
cities and students from America participated in the study. A maths test and mathematical problem posing scheme were used in this study. The meaningful correlation between problem posing and creativity were only obtained in Jiaozhou group students. Besides, whether or not there is a difference between their problem solving skills were also analysed. It was stated that Jiaozhou students were more successful than the other two groups in problem posing. When their creativity was analysed in terms of authenticity, fluency and flexibility; while Jiaozhou students provided creative responses in problem posing according to an image, American students gave creative responses in verbal problems.

Van Harpen and Sriraman (2013) tried to identify students' mathematical creativity by analysing their problem posing skills. It was seen that students who are good at mathematics lessons are not successful in posing problems and they could not use their creativity while posing problems.

Amabile (2016) tells us that the novelty degree of the creativity can change from small changers to the changes in the paradigm. Besides, Amabile (2016) advocates that a similar creativity to the one possessed by Maths teacher cannot be seen in students. This is because of the fact that students cannot reach to mathematics teachers' knowledge. However, Sriraman (2005) claims that students can reach mathematical creativity level by dealing with challenging questions.

\subsection{State Hypotheses and Their Correspondence to Research Design}

I needed to answer the questions which are "Is there a relationship between creativity and mathematical creativity?" and "If so, what are the conditions for achieving the result?". But the correlation between the continuous variable and the discontinuous variable can not be examined. For this reason I have defined the levels of creative thinking as middle and intermediate level. So that the sub-problems are formed as follows:

1) Is there a meaningful difference between mathematical creativity components (flexibility, fluency and authenticity) which were tried to be identified through problem solving and problem posing skills according to creativity levels?

2) Is there a meaningful difference between mathematical creativity components (flexibility, fluency and authenticity) which were tried to be identified through sproblem solving and problem posing skills for both creativity levels separately?

\section{Method}

As my purpose is to determine current situation and to define subject matter in its own conditions without adding anything extra, descriptive model was accepted as a method for this study. This is not an experimental study as I did not manipulate any of the participants. Besides, making a generalization by moving from findings is not among the purposes of this study.

\subsection{Identify Subsections}

\subsubsection{Data Collection Tools}

In order to analyse problem situation of the study, two testing instruments one of which is ready to use were utilized. The ready testing instrument is one version of the creativity test called as "How creative are you?" and it was developed by Whetton and Cameron (2002). The version which was used in this study is the one which was adapted to Turkish by Aksoy (2004). This testing instrument was used after taking necessary permission from the lecturer.

\subsubsection{Creativity Scale-“How Creative Are You?"}

In order to determine general creativity of the prospective teachers, "How creative are you?" creativity scale was used. It was originally published by Whetton and Cameron (2002) with the same name then adapted to Turkish after conducting its validity and reliability by Aksoy (2004). The first 39 items of the scale are in the Likert-type (I agree-Neutral-I disagree) and the last item of the testing instrument is composed of 54 adjectives which questions how participants describe themselves. The maximum score that can be obtained from the scale is 96 and the minimum score is -18 . As a result of the reliability and validity of the scale, internal consistency coefficient of the 39 items was found as (Cronbach Alfa) .94. In conclusion, there are in total 40 items in the final version of the scale. 39 of them are Likert type grading items and 1 categorical item (Aktaran, Koçak, \& İçmenoğlu, 2012).

\subsubsection{Testing Instrument Which Was Used with Problem Solving and Problem Posing Drafts}

This testing instrument was developed by the researcher. In this testing instrument, problem solving and posing drafts were used. On item was given to participants as a geometry problem in the testing instrument and they 
were asked to solve this problem by using as many different methods as they can. The other item was given to participants as a semi-structured geometry situation. They were asked to pose as many problems as they can by using this situation. As geometry in its own nature requires versatile thinking and the ability to approach from different perspectives, it was preferred in the drafts (Balyemez, 2009). In addition to this, having various solution methods found useful in terms of carrying out this study by using geometry as a subject field (Leikin, 2009).

\subsection{Data Analysis}

Ranked mixed method was used in data analysis. Data obtained from solving draft were divided into categories in terms of flexibility, fluency and authenticity according to content analysis from qualitative data analyses for each prospective teacher.

Flexibility: represents the number of different methods used for solving the problem.

Fluency: represents the total number of solution methods used for solving the problem.

Authenticity: represents the number of unique solution methods used by prospective teachers.

A similar method was also used for the problem posing draft except for the authenticity classification. The method followed in problem posing draft is as in the following: Problem created by prospective teachers were analysed according to methods they used in problem solving. If prospective teachers create a problem without using the method used for solving the problem, it is classified under local authenticity. If she/he creates a problem different from all the sample and independent from all the solution methods in problem solving set, it is classified under general authenticity category.

Coding which was made according to content analysis were entered IBM Statistics SPSS 23 packet program by taking 2 expert lecturers and mathematics teachers' opinions.

Steps followed during the study are as in the following:

-The general creativity scores of prospective teachers were coded as 1 (below average level creativity skill) for the score lower than 40 and as 2 (above average level) for scores higher than 40 .

-Methods used by prospective teachers to solve a problem were classified as flexible, fluent and authentic. Besides, problem solving coding and data analysis processes were also taken into consideration. If the participant was coded under the components, his/her assignment to the problem solving and posing skills were made as 3 , if she/he was coded under 2 components, the assignment was made as 2 and for one component, the participant was coded as 1 .

-Similarly, methods used by prospective teachers were classified as flexible, fluent and authentic. Similarly, if the participant was coded under the components, his/her assignment to the problem solving and posing skills were made as 3 , if she/he was coded under 2 components, the assignment was made as 2 and for one component, the participant was coded as 1 . Only local (being creative in his/her own way) and general (being creative according to sample) were analysed separately.

-Among the teachers whose creativity scores were coded as 1 or 2, a comparison was made between their scores they obtained from problem solving and problem posing sub-categories.

\subsection{Participant (Subject) Characteristics}

Fourty-seven teachers participated in this study. They work in private schools and they have their pedagogical formation training from a public university in order to be a public teacher. They have been teaching for more than a year. However, we omitted the data of the three teachers for the sake of having a proper study since they did not complete all the data tools. Thus, sample was formed with forty-four teachers.

\section{Results}

The results of the creativity test scores aiming to test creativity according to teachers' own statements were coded as average level (1) and above average level (2). While 12 of the participating teachers have average level creativity score, the $\mathrm{N}=32$ have above average level creativity score.

After creativity test, teachers were asked to find different solution methods to a given geometry problem. All the produced methods were analyzed one by one and common methods were determined and classified. According to this classification, 5 major categories were identified. They are solutions methods which were produced; according to rules (z rules, etc.), by using triangles and perpendicular, by forming rectangular and with the help of symmetrical axis. There were only two teachers thinking symmetrical axis and their solution methods were 
different from each other. Therefore, for problem solving the fifth category was evaluated as authentic problem solving at the same time.

From problem solving categories, first category could be seen in all teachers, thirty-six teachers produced second category, twenty-two teachers produced third category, fourteen teachers produced fourth category and two teachers produced fifth category solution methods. Only one of the teachers who produced solution methods in the fifth category used 5.1 and the other is the participant who used 5.2 methods and has above average sores. In other categories, teachers who have creativity scores at both levels were determined. Solution methods suggested at different categories were coded under flexibility so as the number of categories, to fluency as for the number of solution methods and to authenticity for the participants who produced a single method according to participants.

Table 1. The classification of categories formed according to content analysis with the number of problem solving and problem posing

\begin{tabular}{|c|c|c|c|c|c|c|c|}
\hline & & Category 1 & Category 2 & Category 3 & Category 4 & Category 5 & Authentic \\
\hline \multirow[t]{2}{*}{$\begin{array}{l}\text { Problem } \\
\text { Solving }\end{array}$} & $\begin{array}{l}\text { Average level creative } \\
\text { teachers }\end{array}$ & 12 & 9 & 3 & 4 & - & - \\
\hline & $\begin{array}{l}\text { Above average level } \\
\text { creative teachers }\end{array}$ & 32 & 27 & 19 & 10 & 2 & 2 \\
\hline \multirow[t]{2}{*}{$\begin{array}{l}\text { Problem } \\
\text { Posing }\end{array}$} & $\begin{array}{l}\text { Average level creative } \\
\text { teachers }\end{array}$ & 9 & 1 & - & 2 & - & 5 \\
\hline & $\begin{array}{l}\text { Above average level } \\
\text { creative teachers }\end{array}$ & 29 & 8 & 2 & 2 & - & 12 \\
\hline
\end{tabular}

If the participants obtained a score from all of the flexibility-fluency-authenticity scores, problem solving total score would be 3 , if the participant got score from two categories, then it would be two and for one category, problem solving total score would be 1 . When Table 1 is analyzed, a correlation between creativity levels of the teachers and their problem solving score was not determined.

In problem posing process, data of the given problem was omitted and teachers were asked to write two or more problems according to given two parallel lines. Thirty-four participants created problems by using the same methods they used in problem solving. It was coded according to the following criteria: the number of different subjects for flexibility, the number of problems for fluency, when a problem was created by moving from a solution that was used by other participants but not by him/her for local authenticity and problems that were created completely different from the sample for general authenticity. According to this, the problems of the participants were classified according to flexibility, fluency and authenticity (local and general). Later on, for the participants who have problems in all the flexibility, fluency and authenticity (local and general) categories, the total problem posing score for them will be 3 . When they have problems in only two of these categories, their problem posing score will be 2 and when they have problems only in one category, their score will be coded as 1 . Problem solving and problem posing skills of the participants according to their creativity levels were compared by using non-parametric Mann Whitney $\mathrm{U}$ and presented in Figure 1.

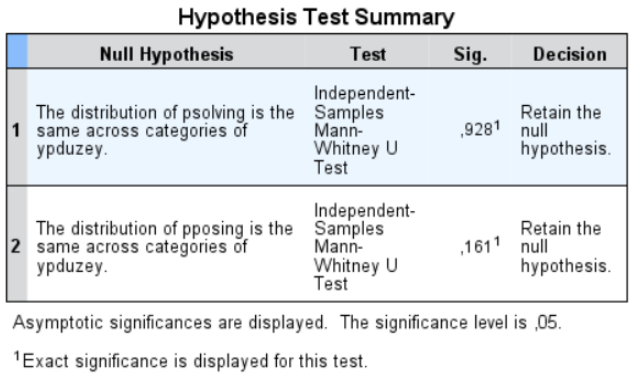

Figure 1. The comparative analysis of problem solving and problem posing achievements according to their creativity levels 
As one can understand from Figure 1, there is not a meaningful difference between teachers' problem solving and problem posing skills according to their creativity levels.

\subsection{Findings the Regarding the First Problem Situation of the Study}

Teachers were compared according to problem solving and problem posing sub-components in accordance with average level and above average level classifications of their creativity. It is understood that there is not a meaningful difference between them according to problem solving components by using non-parametric Mann Whitney $\mathrm{U}$ (flexibility $\alpha=.866$, fluency $\alpha=.458$ and authenticity $\alpha=.928$ ).

Authenticity from problem posing components was analyzed in two ways. Participants who created problems without using any of the solution methods in the solution set obtained because of the problem solving activity but created problems similar to that solving set were coded under local authenticity, participants who created problems, which are completely different from that solving set, were coded under general authenticity. When we compared these sub-components one by one according to their creativity levels, the findings displayed in Figure 2 was obtained. That is, while a meaningful difference could not be determined between participants' creativity levels expressed by themselves and between posing authentic problems according to themselves, there was a significant difference between problems that they produced according to the sample.

\begin{tabular}{|c|c|c|c|c|}
\hline \multicolumn{5}{|c|}{ Hypothesis Test Summary } \\
\hline & Null Hypothesis & Test & Sig. & Decision \\
\hline 1 & $\begin{array}{l}\text { The distribution of genel_ozgunluk } \\
\text { is the same across categories of } \\
\text { ypduzey. }\end{array}$ & $\begin{array}{l}\text { Independent- } \\
\text { Samples } \\
\text { Mann- } \\
\text { Whitney U } \\
\text { Test }\end{array}$ & $.040^{1}$ & $\begin{array}{l}\text { Reject the } \\
\text { null } \\
\text { hypothesis. }\end{array}$ \\
\hline 2 & $\begin{array}{l}\text { The distribution of lokal_ozgunluk is } \\
\text { the same across categories of } \\
\text { ypduzey. }\end{array}$ & $\begin{array}{l}\text { Independent- } \\
\text { Samples } \\
\text { Mann- } \\
\text { Whitney U } \\
\text { Test }\end{array}$ & $.612^{1}$ & $\begin{array}{l}\text { Retain the } \\
\text { null } \\
\text { hypothesis. }\end{array}$ \\
\hline
\end{tabular}

Figure 2. The comparison between general authenticity and local authenticity

By moving from Figure 2, authenticity component, among problem posing components, was discussed as general authenticity sub-component. Later on, whether there was a significant difference between problem posing components according to participants' creativity levels were analyzed and presented in Figure 3.

\begin{tabular}{|c|c|c|c|c|}
\hline \multicolumn{5}{|c|}{ Hypothesis Test Summary } \\
\hline & Null Hypothesis & Test & Sig. & Decision \\
\hline 1 & $\begin{array}{l}\text { The distribution of esneklik_kurma } \\
\text { is the same across categories of } \\
\text { ypduzey. }\end{array}$ & $\begin{array}{l}\text { Independent- } \\
\text { Samples } \\
\text { Mann- } \\
\text { Whitney U } \\
\text { Test }\end{array}$ &, $368^{1}$ & $\begin{array}{l}\text { Retain the } \\
\text { null } \\
\text { hypothesis }\end{array}$ \\
\hline 2 & $\begin{array}{l}\text { The distribution of akıcilik_kurma is } \\
\text { the same across categories of } \\
\text { ypduzey. }\end{array}$ & $\begin{array}{l}\text { Independent- } \\
\text { Samples } \\
\text { Mann- } \\
\text { Whitney U } \\
\text { Test }\end{array}$ &, $302^{1}$ & $\begin{array}{l}\text { Retain the } \\
\text { null } \\
\text { hypothesis }\end{array}$ \\
\hline 3 & $\begin{array}{l}\text { The distribution of genel_ozgunluk } \\
\text { is the same across categories of } \\
\text { ypduzey. }\end{array}$ & $\begin{array}{l}\text { Independent- } \\
\text { Samples } \\
\text { Mann- } \\
\text { Whitney U } \\
\text { Test }\end{array}$ & $.040^{1}$ & $\begin{array}{l}\text { Reject the } \\
\text { null } \\
\text { hypothesis }\end{array}$ \\
\hline
\end{tabular}

Figure 3. The comparison of problem posing components

When Figure 3 is analyzed, it was found that the comparison about the problem posing components of the teachers who have average and above average level creativity was found meaning only in terms of authenticity component.

Besides, while some of the teachers, who have above average-level creativity score could not create authentic problems; there are teachers who can pose authentic problems even though they have average level creativity. 


\subsection{Findings Regarding the Second Problem Situation of the Study}

When the correlation between problem posing components and problem solving components for teachers who have above average creativity level.

Table 2. Correlations determined between problem solving and problem posing components of teachers who think they have above average level creativity

\begin{tabular}{lll}
\hline Relational Analysed Components & Sig. (2-tailed) & Spearman Correlation Coefficient \\
\hline Flexibility (problem solving) and Fluency (problem solving) & .001 & .561 \\
Flexibility (problem posing) and Fluency (problem posing) & .038 & .368 \\
Flexibility (problem posing) and Authenticity (problem posing) & .017 & .421 \\
\hline
\end{tabular}

When correlations between problem solving and problem posing components of teachers who have average level creativity were analysed.

Table 3. Correlations determined between problem solving and problem posing components of teachers who think they have average level creativity

\begin{tabular}{lll}
\hline Relational Analysed Components & Sig. (2-tailed) & Spearman correlation coefficent \\
\hline Flexibility (problem solving) and Fluency (problem solving) & .003 & .775 \\
Fluency (problem solving) and Fluency (problem posing) & .030 & .626 \\
\hline
\end{tabular}

A meaningful positive correlation can be seen in Tables 4 and 5 between flexibility (problem solving) and fluency (problem solving) components at each two creativity levels. That is, as the number of problems increases having different styles in thinking also increase. Therefore, solving a maths problem by using different methods supports flexible thinking.

\section{Conclusion and Discussion}

In this study aiming to analyze the correlation between creativity and mathematical creativity, methods, which have also been used by different researchers before (Haylock, 1997; Kim et al., 2004), were utilized. In determining mathematical creativity, tools like problem solving by using different methods and posing more than one problems were used; the data was analyzed according to flexibility, fluency and authenticity components. When Table 3 is analyzed, it is seen that participants who created problems according to different mathematical relations or about a different topic have above-average level creativity when compared with other participants in the sample. Thus, the skill, which identifies the correlation between creativity and mathematical creativity, was determined as (general) authenticity component. Teachers can solve a geometry problem by using different methods but it is an inevitable situation that they are not able to present an authentic method. Meissner (1999) advocates that to be able to produce creative ideas, teachers and students need to have something more than a whole and complete mathematical knowledge. The participants of the study are teachers who are teaching in a private school and trying to complete their pedagogical training in a public university to be eligible to be a teacher in a public school. Therefore, it was determined in the study that they used many different methods in problem solving. However, as Meissner (1999) stated in order to be a creative mathematics teacher, a complete mathematical knowledge is not sufficient.

When we consider the fact that teachers are important factors even role models in the learning process of the students, it is seen that participants can enable the suggestion of Drefyus and Eisenberg (1996) about giving students the skill of being able to reach a problem from different perspectives. From this perspective, it is pleasing result that teachers can encourage their students in their mathematics learning process.

Although creative thinking is the essence of mathematics (Ginsburg, 1996), mathematical programs are not interested in this essence in details (Davis, 1986).

Solving a maths problem by using different methods can be a sing for using creativity (Krutetskii, 1976; Silver, 1997). Although there are researchers who states that flexibility thinking skill complies with creative skills (Kresswtter, 1983; Levenson, 2013), it is also possible to say that divergent and flexible thinking also feeds 
creativity (Atasoy et al., 2007). For example, in Guilford's (1967) study it is stated that suggesting only a single solution method is convergent thinking and producing multiple solution method through flexible thinking is divergent thinking. Therefore, the result found for the problem solving is not contrary to the literature. However, a similar result could not be determined for flexibility component of the problem posing skill. Teachers whose creativity levels are above average could not be as successful as in the problem solving while posing problems. This situation makes us think that teachers have a lot of experience in problem solving but they have relatively less experience in problem posing.

One of the most important results of the study is that although all prospective teachers who solve a problem by using a different method stated in the sample had above average level score from creativity scale, only two (different from the sample) of the teachers who had above average level score solved the problem by using an authentic method. The other one is teachers who posed authentic problems according to sample are the participants who had above average level from "how creative are you?" scale, but not all the participants who had above average level score from this scale could pose authentic problems according to the sample.

According to the literature, there are researchers who classify mathematical creativity as relative and unconditioned (Liljedah \& Sriraman, 2006; Lytton, 1971). In fact, there is a similar classification made except one difference. Mathematical creativity was classified as; local (creative thinking in his/her own way) and general (creative thinking according to the sample). If we combine the result obtained from this study with the ones from the previous studies, we can get the following pattern.

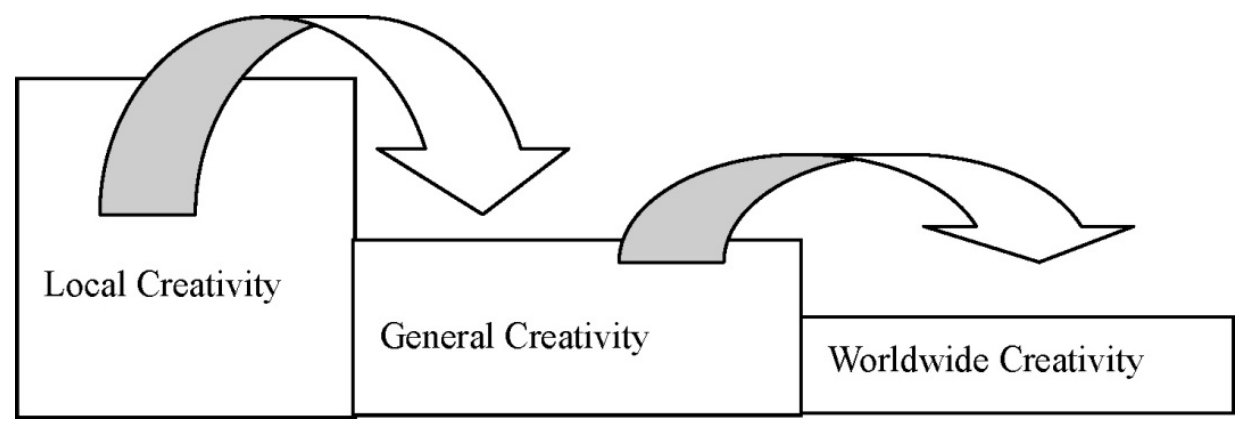

Figure 4. A conceptual framework suggestion for Mathematical Creativity (Thinking out of the box)

A person who is worldwide creative possesses both general creativity (according to any kind of sample) and local creativity (according him/her). A person who is at the general creativity level possesses local creativity. We can say that vice versa is true. Each student must be motivated to think creatively according to himself/herself and then the sample (Figure 4).

It is pointed out that mathematics teachers should be an expert at his/her field, should have high internal motivation and have original ideas to improve mathematical creativity (Gregoire, 2016). For this reason, for teachers who have general creativity and who produced authentic problems according to sample, it can be said that they have potentials to encourage their students to think creatively. However, we need to conduct a new study to analyze this interaction. That is, is a teacher who really has above average level creativity using materials, problems and activities supporting students' creativity?

Finally, according to the teachers' creativity that they stated, we can talk about their mathematical creativity only if they can pose an authentic problem. According to the information that teachers stated although they different creativity levels, a meaningful difference could not be found between their flexible thinking skills and in my opinion, this is an important results in terms teaching mathematics because according to results, teachers participating in this study are individuals who are thinking in the same patterns while doing mathematics. In Turkey, central testing started to be used in 1974 and the importance of this central testing increased each following year and became a vital issue. Therefore, it is also not possible for mathematics teachers to be influenced from this atmosphere. If we consider the fact that they received their mathematics training according to the questions used in the central testing system and if take into account that they teach in the same way, it will not be true to expect from them to think flexibly in a way to create a difference in mathematics. 


\section{Suggestions}

"Sir/Madam I understood the question that you solved in the classroom but when I go home and try to do another question, I cannot do it, what is the reason of this?"

Does creativity come naturally, or can you be creative through learning? If it comes naturally, can a creative person keep this skill without any decrease in his entire education? If it is a skill, which can be learnt afterwards, how effective is education to make people acquire this skill? I will not be wrong to say that education has a role in both cases. For students' current or future creativities, teachers will play an active role in every field. When we analyze in terms of mathematics lessons, only methodological solutions can discourage current creativity or creativity that we can acquire or improve in the future. A student's question highlighted above can point out this issue. Students should have enough time for thinking for each question and they should be asked to think deeply for each question. When teachers solve the questions himself, students might memorize the solution. On the other hand, she/he might feel insecure through thinking that she/he cannot find similar words, numbers or correlations in a problem that she encountered as she/he could not understand or she/he misunderstood the solution. At this point, we can philosophize about the concepts and interrogate problems.

Interrogations like determining concepts about problems, using metaphors about the concepts, analyzing the correlations between concepts will contribute creativity.

Thus, students can understand and determine the logic behind the solutions and they can reach their own solutions when they face problems by using similar strategies or by developing their own strategies.

\section{References}

Aktamış, H., \& Ergin, Ö. (2006). Fen Eğitimi ve Yaratıcılık. Dokuz Eylül Üniversitesi Buca Eğitim Fakültesi Dergisi, 20, 77-83.

Amabile, T. M. (2016). The Motivation for Creativity. Scientists Making a Difference: One Hundred Eminent Behavioral and Brain Scientists Talk about Their Most Important Contributions (p. 275).

Balyemez, S. (2009). Dil Bilgisi Öğretiminde Diğer Derslerden Yararlanma. Cagdas Egitim Dergisi, 365.

Chamberlin, S. A., \& Moon, S. M. (2005). Model-eliciting activities as tool to develop and identify creativity gifted mathematicians. Journal of Secondary Gifted Education, 17(1), 37-47. https://doi.org/10.4219/jsge-2005-393

Coade, N. (1997). Be Creative (Her Koşulda Yaratıcı Olmak) (Çev.: Aydın Ekim Savran, 2002). İstanbul: Epsilon Yayıncılık Hizmetleri Tic. San. Ltd. Şti.

Ervynck, G. (1991). Mathematical creativity. In D. Tall (Ed.), Advanced mathematical thinking (pp. 42-52). Kluwer Academic Publishers New York.

Grégoire, J. (2016). Understanding Creativity in Mathematics for Improving Mathematical Education. Journal of Cognitive Education and Psychology, 15(1), 24. https://doi.org/10.1891/1945-8959.15.1.24

Guilford, J. P. (1967). Creativity: Yesterday, today and tomorrow. The Journal of Creative Behavior, 1(1), 3-14. https://doi.org/10.1002/j.2162-6057.1967.tb00002.x

Güleryüz, H. (2001). Eğitim Programlarının Dili ve Yaratıcı Öğrenme [The Language of Educational Programs and Creative Learning]. Ankara: PagemA Yayıncılık.

Haylock, D. (1997). Recognizing mathematical creativity in school children. International Reviews on Mathematical Education, 29(3), 68-74.

Haylock, D. W. (1987). A framework for assessing mathematical creativity in school chilren. Educational Studies in Mathematics, 18(1), 59-74. https://doi.org/10.1007/BF00367914

Haylock, D. W. (1985). Conflicts in the assessment and encouragement of mathematical creativity in school children. International Journal of Mathematical Education in Science and technology, 16, 547-553. https://doi.org/10.1080/0020739850160412

Kim, H., Cho, S., \& Ahn, D. (2004). Development of mathematical creative problem solving ability test for identification of gifted in math. Gifted Education International, 18, 164-174. https://doi.org/10.1177/026142940301800206

Koçak, R., \& İçmenoğlu, E. (2012). Üstün Yetenekli Öğrencilerin Duygusal Zek ve Yaratıcılık Düzeylerinin Yaşam Doyumlarını Yordayıcı Rolü [Emotional Intelligence in Gifted Students and The role of their creativity in their future lives]. Türk Psikolojik Danışma ve Rehberlik Dergisi, 4(37), 73-85. 
Krutetskii, V. A. (1976). The psychology of mathematical abilities in school children. Univesity of Chicago Pres, Chicago.

Laycock, M. (1970). Creative mathematics at Nueva. Arithmetic Teacher, 17, 325-328.

Lee, K. S., \& Seo, J. J. (2003). A development of the test for mathematical creative problem solving ability. Research in Mathematical Education, 7(3), 163-189.

Lee, K. S., Hwang, D. J., \& Seo, J. J. (2003). A development of the test for mathematical creative problem solving ability. Journal of the Korea Society of Mathematical Education Series: Research in Mathematical Education, 7(3), 163-189.

Leikin, R. (2009). Exploring mathematical creativity using multiple solution tasks. In R. Leikin, A. Berman, \& B. Koichu (Eds.), Creativity in mathematics and the education of gifted students (pp. 129-145). Rotterdam: Sense Publishers.

Leikin, R., \& Lev, M. (2013). Mathematical creativity in generally gifted and mathematically excelling adolescents: What makes the difference? ZDM-The International Journal on Mathematics Education, 45(2), 183-197.

Liljedahl, P., \& Sriraman, B. (2006). Musings on mathematical creativity. For the Learning of Mathematics, 26(1), 17-19.

Lubart, T. I. (2003). In search of creative intelligence. In R. J. Sternberg, J. Lautrey, \& T. I. Lubart (Eds.), Models of intelligence: International perspectives (pp. 279-292). Washington, DC: American Psychological Association.

Mann, E. L. (2005). Mathematical creativity and school mathematics: Indicators of mathematical creativity in middle school students (Doctor of Philosophy). University of Connecticu.

Meissner, H. (1999). Creativity and mathematics education. Creativity and mathematics education of the international conference, July 15-19, Muenster, Germany.

Robinson, K. (2001). Out of Our Minds, Learning to be Creative. By Capstone Publishing Limited, UK.

Silver, E. A. (1994). On mathematical problem posing. For the Learning of Mathematics, 14(1), 19-28.

Silver, E. A. (1997). Fostering creativity through instruction rich in mathematical problem solving and problem posing. ZDM, 29(3), 75-80. https://doi.org/10.1007/s11858-997-0003-x

Sönmez, V. (1993). Yaratıcı Okul, Öğretmen, Öğrenci, Yaratıcılık ve Eğitim, Türk Eğitim Derneği Ĕ̆itim Dizisi. Şafak Matbaacilık: Ankara.

Sriraman, B. (2004). The Characteristics of Mathematical Creativity. Mathematics Educator, 14(1), 1934.

Sriraman, B. (2005). Are giftedness and creativity synonyms in mathematics? Journal of Secondary Gifted Education, 17(1), 20-36. https://doi.org/10.4219/jsge-2005-389

Sriraman, B. (2009). The characteristics of mathematical creativity. The International Journal on Mathematics Education [ZDM], 41, 13-27. https://doi.org/10.1007/s11858-008-0114-z

Sriraman, B., Yaftian, N., \& Lee, K. H. (2011). Mathematical creativity and mathematics education. In The elements of creativity and giftedness in mathematics (pp. 119-130). Sense Publishers. https://doi.org/10.1007/978-94-6091-439-3_8

Tammadge, A. (1979). Creativity, Presidential address to the Mathematical Association. The Mathematical Gazette, 63, 145-163. https://doi.org/10.2307/3617885

Van Harpen, X. Y., \& Sriraman, B. (2012). Creativity and mathematical problem posing: An analysis of high school students' mathematical problem posing in China and the USA. Educational Studies in Mathematics, 82(2), 201-221. https://doi.org/10.1007/s10649-012-9419-5

Wakefield, J. F. (1992). Creative Thinking, Problem Solving Skillls and The Arts Orientation. Ablex Publishing Corporation Norwood, New Jersey. 


\section{Appendix A}

Content Analysis of Problem Solving in Multiple ways

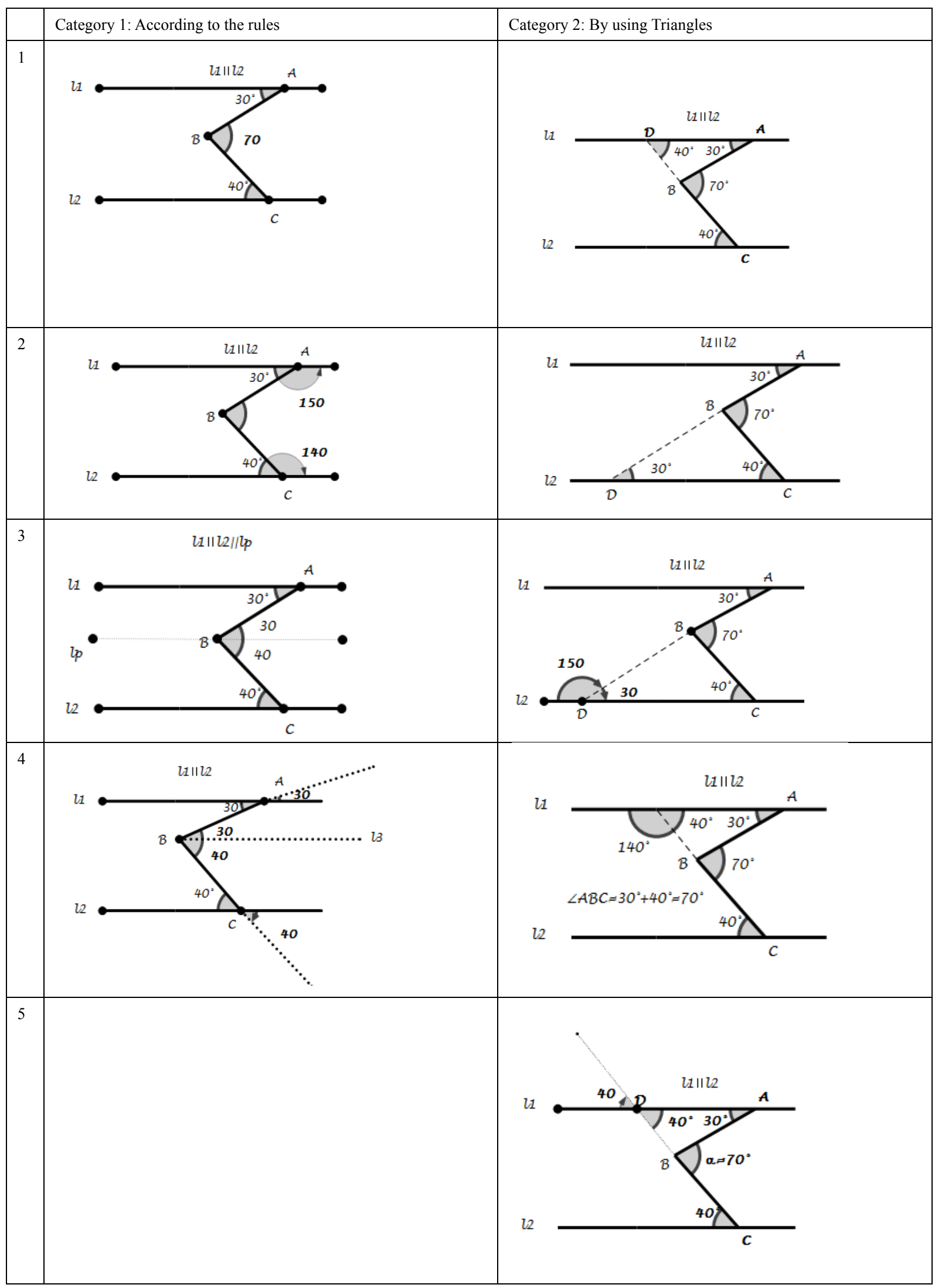




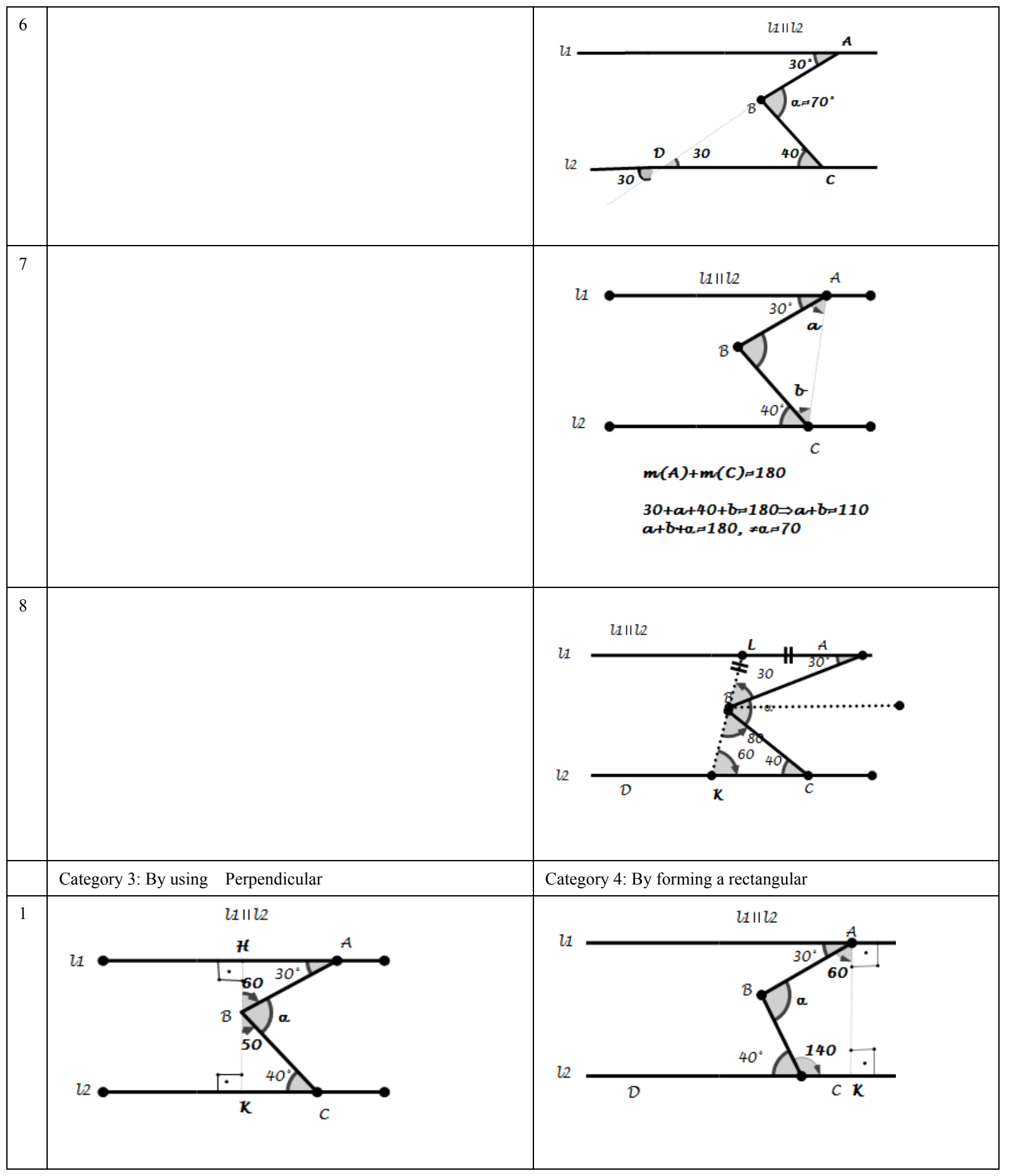




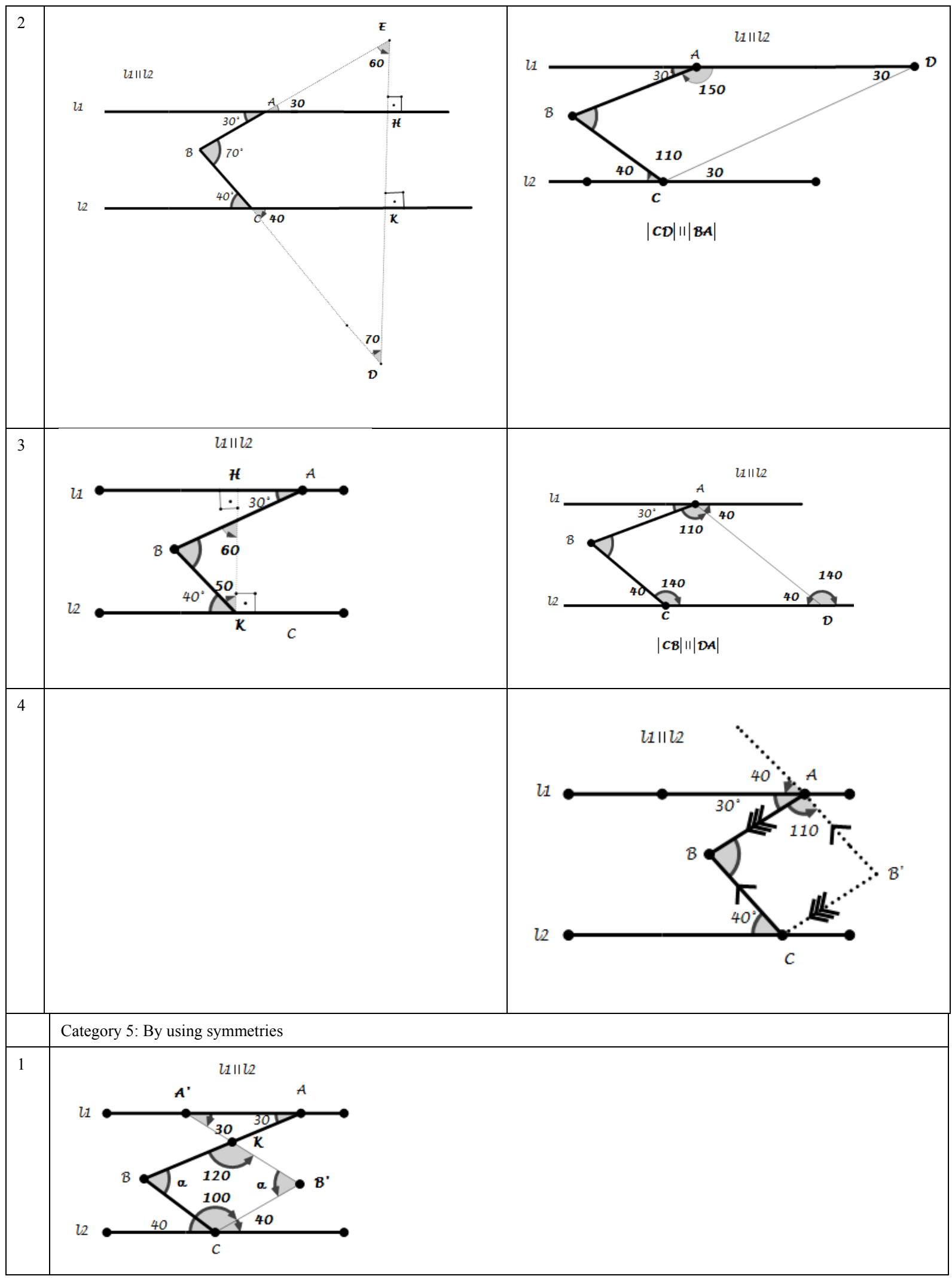




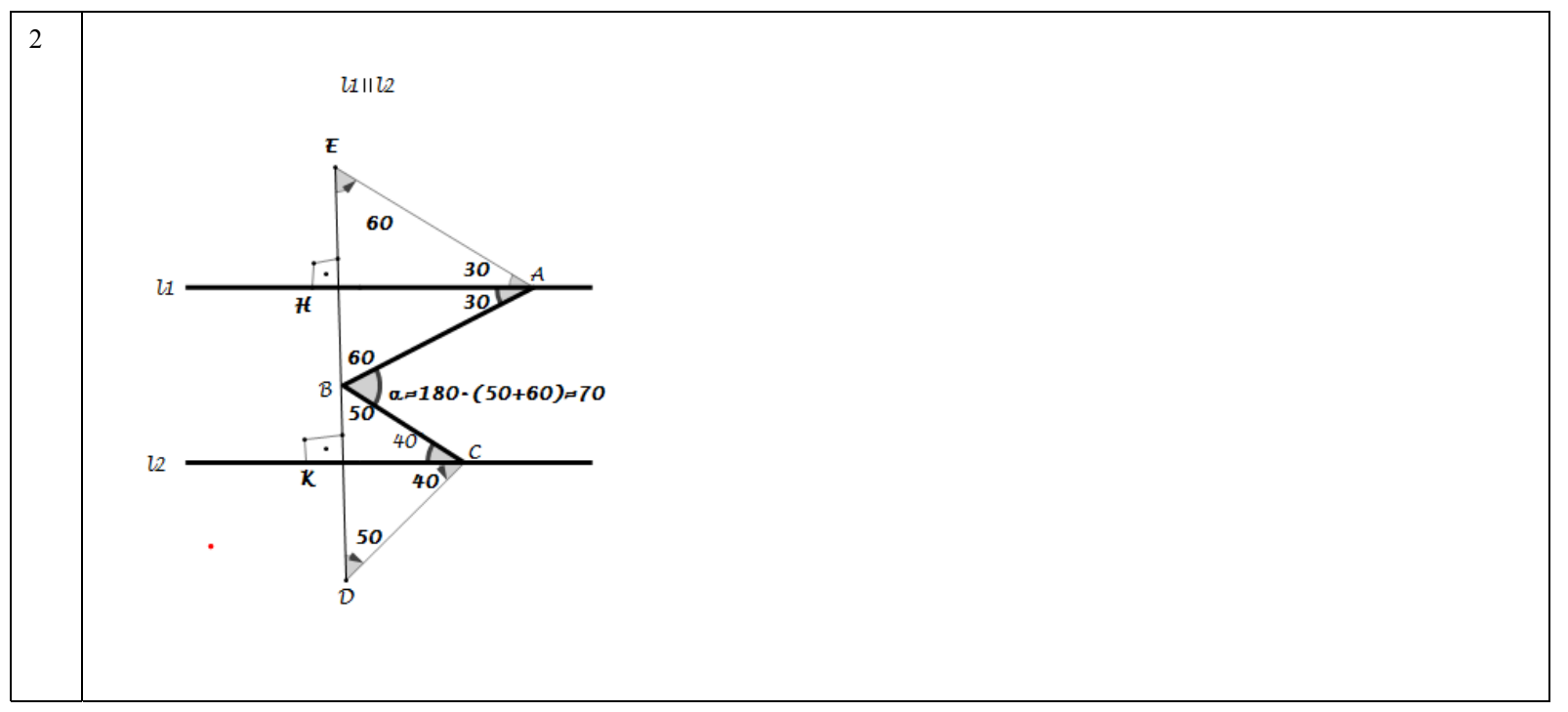

\section{Copyrights}

Copyright for this article is retained by the author(s), with first publication rights granted to the journal.

This is an open-access article distributed under the terms and conditions of the Creative Commons Attribution license (http://creativecommons.org/licenses/by/4.0/). 